\title{
Hajnal Zsolt[1]: Fogyasztói alapjogok a hatályos magyar jogi szabályozás és az európai uniós fejlődési tendenciák tükrében
}

Debreceni Jogi Műhely, 2009. évi (VI. évfolyam) 2. szám (2009. április)

\section{Bevezetés}

A hatékonyan müködő piacgazdasági struktúra alapját olyan jogok érvényre juttatása képezi, amelyek autonómiát biztosítanak az egyének számára a gazdasági életben való mozgás tekintetében, azaz lehetővé teszi számára, hogy akár valamely áru vagy szolgáltatás értékesítőjeként, akár a másik oldalon fogyasztóként az üzleti, gazdasági élet és az ennek keretében szükségszerüen létrejövő jogviszonyok minden tekintetben önálló alanyává válhasson. A piacgazdasági viszonyok között ugyanakkor meglehetősen érzékeny egyensúly alakult ki a piaci szereplők egyéni autonómiája és azok törvényes jogainak és érdekeinek védelme között. Az egyén autonóm mozgásterének határát képezi ugyanis mások autonóm mozgásterének a védelme. Nem elegendő ugyanis, hogy a cselekvés lehetősége adottá váljon, szükséges az is, hogy megfelelő garanciák kerüljenek kiépítésre a jogrendszerben, annak érdekében, hogy a gyengébb piaci alkupozícióban lévő fél jogi és gazdasági érdekeinek védelme is megvalósítható legyen. Tulajdonképpen ennek a célnak a megvalósítását szolgálja a fogyasztóvédelem intézményrendszerének életre hívása és a rá vonatkozó anyagi és eljárásjogi szabályok megalkotása. A folyamatosan változó piaci struktúrák, a fejlődő gazdaság ugyanakkor számos esetben továbbra is új kihívások elé állítja a jogalkotót, a fogyasztó hatékony védelmét biztosító jogszabályi struktúra kialakításának igényével.

A fogyasztóvédelmi jog egyébként egy viszonylag új, ugyanakkor mégis sokszínű, plurális jogterület. Egyfajta vegyes szakjog, amely a közjog és magánjog határán helyezkedik el. Számos szabályt tartalmaz a közigazgatási jog, a polgári jog, illetve a büntetőjog területén, anyagi jogi és eljárásjogi szabályokat egyaránt.

Mára alapvetően kétféle megközelítése alakult ki a fogyasztóvédelmi tárgyú jogi szabályozásnak, az egyik a protekcionista szemlélet, a másik pedig a „Bourgoignie-féle” irányzat. A protekcionista megközelítés a fogyasztók védelmét protekcionista jellegü jogi szabályozás által kívánja megvalósítani, azt a szemléletet tükrözve, hogy a fogyasztók a szabad piaci verseny áldozatai, míg a „Bourgoignie-féle” megközelítés a védelem helyett a megfelelő jogi támogatásra helyezi a hangsúlyt, elsősorban a fogyasztók megfelelő oktatása, a tájékoztatáshoz való jog, a jogi védelemhez és jogorvoslathoz való jog deklarálásával és megfelelő jogi garanciáinak kiépítése által[2]

Abszolút védelem kialakítása a folyamatosan változó gazdasági és társadalmi viszonyok között nyilvánvalóan irreális elvárás volna, ezért sokkal hatékonyabb megoldást biztosít a védelemhez szükséges alapvető fogyasztói alapjogok meghatározása és a fogyasztók széleskörü támogatása ezek megismerése és érvényesítése tárgyában.

\section{A fogyasztói alapjogok kialakulásának és elismerésének történeti dimenziói}

Hosszú volt az a jogtörténeti folyamat amely a fogyasztóvédelem mai szemléletének kialakulásához vezetett és még koránt sem tekinthető lezártnak. Az állami szerepvállalás mértéke az elmúlt évszázadokban folyamatosan változott, mind a gazdaság, mind a jogi szabályozás területén.

Gazdasági téren a 19. század végére mindinkább elterjedté vált a „laissez-faire” elvének gyakorlati alkalmazása, amely az önszabályozó piac gazdasági rendszerére építve, az állami be nem avatkozás doktrínájának érvényesítésével kívánta a gazdasági fejlődést ösztönözni. 
Ezzel párhuzamba állítható az a jogi szabályozásban bekövetkező folyamat, amely annak a visszavonhatatlan deklarációjához vezetett, hogy vannak olyan elidegeníthetetlen szabadságjogok, amelyeket még maga az állam sem korlátozhat. Ezen jogok közé sorolható többek között az élethez való jog, a tulajdonhoz való jog, az egyesülési és gyülekezési szabadság, a lelkiismereti és vallásszabadság, a szólás-és sajtószabadság, a személyi szabadsághoz való jog. elősegíteni.

A „laissez-faire” elvének gazdasági oldalról történő végső elutasítását elsősorban a nagy gazdasági világválság indukálta. A gazdasági világválságra adott válaszok sorában jelent meg a keynesi újszerü gondolkodásmód, amely egy gyökeresen új gazdaságpolitikai szemléletet tükrözött az állam, elsősorban gazdasági jellegü szerepvállalása terén. Az uralkodó neoklasszikus közgazdaságtani iskola általánosan elfogadta a Say törvényt, amely szerint "a kínálat megteremti keresletét", vagyis minden árut el lehet adni a piacon, mert a termék értékesítője a termelésben részt vevő termelési tényezőknek, a munkásoknak, a tőkéseknek és a földtulajdonosoknak bért, kamatot, illetve földjáradékot fizet, és ezek vásárlóerőként fognak jelentkezni a piacon. A gazdasági recessziónak és munkanélküliségnek azonban a Say törvénnyel szemben az volt az elsődleges oka, hogy a termelés és a vásárlóerő soha sem lesznek teljesen összhangban, mert a fejlett piacgazdasági viszonyokban semmi sem garantálja, hogy a vállalkozók annyit ruházzanak be, mint amennyit a jövedelmet kapó emberek megtakarítani szándékoznak[3]. Az éjjeliőr állam helyett éppen ezért egy aktívabb szerepet vállaló állam képe formálódott meg.

A gazdasági recesszió kezdete és a gazdasági-modellek újragondolásával nagyjából egy időben az állam jogi, politikai funkciói is változásokon mentek keresztül. Megjelentek az ún. második generációs jogok, amelyek a klasszikus jogokhoz képest alapvető változást hoztak abban, hogy többé már nem elegendő az állam be nem avatkozása, hanem éppenséggel aktív szerepvállalásra kényszerítik.

A szociális jogok első ízben a törvényalkotás folyamatában jelentek meg, majd az első világháború után egyre több esetben az alkotmányokban is megfogalmazásra kerültek, mint alkotmányos jogok. A II. világháború idején hatályos német jogi szabályozás jogpozitivista szemléletének retrográd következményeiböl okulva bekövetkezett az emberi jogok eszméjéhez történő visszatérés. Az emberi jogok természetjogi felfogása kellő támasz az alapjogok tartalmának csorbításával szemben, valamint alapot szolgáltat arra is, hogy kifejezésre juttassa a jogok védelmének egyetemlegességét. A történelmi tapasztalatok mélyreható felfogásbeli megújulást eredményeznek, amelyek elvezetnek a jogállam fogalmának újraértelmezéséhez is. A jogállamiság többé már nem jelentheti pusztán a formális jogbiztonságot, hanem kiegészül egy materiális vetülettel is, amelyet az igazságosság eszménye hordoz. Ahogy Gustav Radbruch 1946-os Gesetzliches Unrecht und übergesetzliches Recht címü munkájában fogalmazott, a pozitív jogot igazságtalannak kell tekinteni, ha a törvény és az igazságosság közötti ellentmondás olyan elviselhetetlen mértéket ölt, hogy a törvénynek mint igazságtalan jognak, az igazságosság eszménye előtt feltétel nélkül meg kell hátrálnia[4].

Az 1940-es évek közepétől kezdve erősödött a szociális alkotmányozás, amely egészen az 1980-as évekig tartott, majd kiegészült a harmadik generációs jogok egyre szélesebb körben történő elismerésével (környezethez való jog, beteg jogok, fogyatékosok jogai)[5].

Az elözőekben bemutatott emberi szabadságjogok rendszerét a XX. század közepétől kiegészítették az egyén piaci autonómiájának védelmét szolgáló fogyasztói jogok. A fogyasztóvédelmi tárgyú szabályozás az alapvetően gyengébb szerződéses alkupozícióban lévő fogyasztó jogi védelmének megvalósítását célozza. Az Amerikai Egyesült Államokban az 1960-as évek elején deklarálták az alapvető fogyasztói jogokat, így az információhoz, a biztonsághoz, a választáshoz és a meghallgatáshoz való jogot, mint az egyéni szabadságjogok 
egyfajta új katalógusát[6]. A fogyasztói jogok számos országban pedig külön alkotmányos szintủ szabályozást nyertek. A svájci, portugál, spanyol alkotmányok kifejezetten deklarálnak egyes fogyasztói alapjogokat, míg más országok jogrendszerében mint egyfajta kvázi alkotmányos alapjogként jelennek meg külön jogi szabályozás tárgyaként[7]. A spanyol alkotmány 51. cikkének értelmében például a közhatalom kötelezettsége, hogy biztosítsa a fogyasztók védelmét és hatékony intézkedésekkel védje biztonságukat, egészségüket és jogos gazdasági érdekeiket. A portugál alkotmány ugyancsak rögzít egyes a fogyasztók védelmével és tájékoztatásával kapcsolatos jogokat, illetve ezen túlmutatva a fogyasztók kártérítésére vonatkozó szabályokat is megfogalmaz[8].

Az Európai Tanács által 1975. április 14-én elfogadott, „Az Európai Gazdasági Közösség első, előzetes programja a fogyasztók védelmének és informálásának politikájáról” címet viselő határozat alapján a fogyasztói jogok közzé tartozik a fogyasztók egészségének és biztonságának védelme, a fogyasztók vagyoni érdekeinek védelme, a jogorvoslathoz való jog, a tájékoztatáshoz és oktatáshoz való jog, illetve a meghallgatáshoz és a fogyasztók érdekeinek képviseletéhez való jog egyaránt. A Maastrichti Szerződés pedig a számos új közösségi kompetencia között a hivatalos politikák közzé emelte a fogyasztóvédelmet is (129/A cikk)[9].

Míg nyugat-európai országokban már az 1970-es évektől kezdődően megjelent az igény a megfelelő fogyasztóvédelmi szabályozás kialakítására, addig Magyarországon csupán több mint egy évtizeddel később, az 1980-as években fogalmazódott meg, elsősorban elvi szinten ennek szükségessége.

\section{Fogyasztói alapjogok Magyarországon}

A magyar Alkotmány kifejezetten nem rögzíti a fogyasztói jogokat, ugyanakkor az Alkotmányban rögzített emberi és polgári alapjogok, a gazdasági és szociális jogok, valamint az igazságszolgáltatáshoz való jog analógia útján tekinthetőek a fogyasztói érdekek védelmére szolgáló alkotmányos rendelkezéseknek is[10]. Vannak tehát olyan az Alkotmányban megfogalmazott rendelkezések, amelyek értelmezésének jelentős hatásai lehetnek a fogyasztóvédelem müködési határainak megszabása tárgyában. Az alkotmányban szabályozott alapjogok egyébként nem állnak meg önmagukban, szükséges a megfelelő törvényi szintü szabályozás is. Erre egyébként az Alkotmány maga is utal a 8 . § (2) bekezdésében, amely szerint a „Magyar Köztársaságban az alapvető jogokra és kötelességekre vonatkozó szabályokat törvény állapítja meg, alapvető jog lényeges tartalmát azonban nem korlátozhatja."

\section{A gazdasági és szociális jogok fogyasztóvédelmi megközelítésben}

A gazdasági és szociális jogok közzé tartozik a tulajdonhoz való jog, a tulajdonképpeni szociális jogok, a munkához való jog, a házasság és a család védelme, valamint a gyermekek jogai és védelme egyaránt. A tulajdoni viszonyok adják a jogviszonyok tipikusan statikus elemét, szemben a kötelmi joggal, amely a társadalom jogviszonyainak dinamikáját teremti meg. Ez utóbbi megfelelő müködésének az alapvető feltétele, hogy elismerést nyerjen a vállalkozás joga, a gazdasági verseny szabadsága és a szerződési szabadság.

Az Alkotmány 9.§-ának értelmében „Magyarország gazdasága piacgazdaság, a Magyar Köztársaság elismeri és támogatja a vállalkozás jogát és a gazdasági verseny szabadságát." Ezek érvényesülésének tárgyában ugyanakkor bizonyos mérvű korlátok szükségszerüen megmutatkoznak, így például a fogyasztóvédelmi tárgyú törvényi rendelkezések által támasztott követelmények. Az Alkotmánybíróság a 33/1993 (V. 28) határozatában rögzítette, hogy a piacgazdasághoz senkinek sincs joga, az nem tekinthető alapjognak. A piacgazdaság alapvetően gazdaságpolitika, amely egyes alkotmányos érdekek miatt ugyancsak korlátozható. A vállalkozás joga azonban az Alkotmánybíróság 21/1994 (IV. 16.) határozata 
alapján tekinthető valódi alapjognak, abban az értelemben, hogy a vállalkozóvá váláshoz való jogot törvény lényege szerint nem korlátozhatja. Ugyanakkor lehetségesek olyan jogszabályi korlátok, amelyek például a fogyasztói érdekek érvényesülésének kifejeződését tükrözve, korlátozhatják a vállalkozás jogának a tulajdonképpeni gyakorlását, hiszen maga az $\mathrm{AB}$ határozat is oly módon fogalmaz, hogy a ,vállalkozás joga annyit jelent - de annyit alkotmányos követelményként feltétlenül-hogy az állam ne akadályozza meg, ne tegye lehetetlenné a vállalkozóvá válást”. Ehhez képest a szerződési szabadság az Alkotmánybíróság 32/1991 (VI.1.) határozata alapján „,...alkotmányosan még lényegi tartalmát illetően is korlátozható, amennyiben a korlátozás végső eszközének fennállnak az alkotmányos indokai”. [11]

A vállalkozás jogának, a gazdasági verseny szabadságának, illetve a szerződési szabadságnak számos, a fogyasztók érdekeinek védelmét szolgáló korlátozását felfedezhetjük jogrendszerünkben. Ezek a korlátozások elsősorban a közjogi jellegüek és mint alkalmazott szankciók jelentkeznek (például üzletbezárás a jogsértés megállapítása esetében), míg egyes jogi konstrukciói a magánjog területén fogalmazódtak meg (például a kötelező jótállás intézménye).

\section{A fogyasztói érdekek védelmét is szolgáló alkotmányos rendelkezésekről}

\section{A) A fogyasztók egészségének és biztonságának védelme}

A szociális jogok körébe tartozik az egészséghez való jog. Az Alkotmány rögzíti, hogy a „Magyar Köztársaság területén élöknek joguk van a legmagasabb szintü testi és lelki egészséghez." A legmagasabb szintü testi és lelki egészség teljesítésének követelménye a társadalmi és gazdasági élet rendszerének egészét áthatja. Ennek megfelelően alapvető követelményként jelentkezik a fogyasztóvédelem rendszerében is. A fogyasztók egészsége védelmének nélkülözhetetlen eleme az, hogy csak biztonságos árut lehessen forgalomba hozni. A fogyasztók életének, egészségének és biztonságának védelmére vonatkozó részletes szabályokat határoz meg az 1997. évi CLV. törvény a fogyasztóvédelemről (továbbiakban: Fgytv.), amelynek értelmében alapvetően a gyártó köteles gondoskodni az áru biztonságosságáról. A forgalmazó ugyanakkor nem hozhat forgalomba olyan árut, amelyről tudja vagy a rendelkezésére álló tájékoztatás vagy szakmai ismeret alapján tudnia kellene, hogy az áru nem biztonságos. A továbbiakban az Fgytv. arról rendelkezik, hogy a gyártó vagy a forgalmazó, akinek a rendelkezésére álló tájékoztatás vagy szakmai ismeret alapján tudnia kell, hogy az általuk forgalomba hozott áru nem felel meg a biztonságossági követelménynek, köteles a hatáskörrel rendelkező hatóságot haladéktalanul tájékoztatni, egyidejüleg rendelkezésére bocsátani különösen a fogyasztókat érintő veszély elhárítására tett intézkedéseire vonatkozó adatokat. A törvény orientáló rendelkezéseket tartalmaz annak tárgyában, hogy miként lehet megítélni valamely áru biztonságosságát, ha az nem került valamely jogforrásban, külön szabványban meghatározásra. Amennyiben az áru biztonságosságát jogszabály vagy nemzeti szabvány nem határozza meg, az áru akkor minősül biztonságosnak, ha a fogyasztó életét, egészségét, testi épségét a rendeltetésszerü vagy az ésszerüen várható használat időtartama alatt nem, vagy csak a rendeltetésszerü vagy ésszerüen várható használatával járó legkisebb mértékben veszélyezteti. Amennyiben pedig a kockázat figyelmeztetés nélkül nem észlelhető azonnal, a gyártó köteles a fogyasztót írásban figyelmeztetni olyan módon, hogy a fogyasztó felmérhesse az áru rendeltetésszerü vagy ésszerüen várható használatával járó veszélyt, illetve megtehesse a veszély elleni óvintézkedéseket. A figyelmeztetés ugyanakkor nem mentesíti a gyártót és a forgalmazót az áru biztonságosságával kapcsolatos kötelezettségei alól.

\section{B) Az oktatáshoz való jog[12]}

Az Alkotmány 70/F § (1) bekezdése rögzíti, hogy a „Magyar Köztársaság biztosítja az állampolgárok számára a müvelődéshez való jogot.” 
A müvelődéshez való jog részterülete az oktatás, amely több szinten érhető el, az ingyenes és kötelező általános iskolai oktatástól a képességek alapján hozzáférhető közép- és felsőfokú iskolai oktatásig. Ebben a kialakult oktatási rendszerben mindinkább elismert területnek tekinthető a fogyasztók oktatása is. A fogyasztóvédelmi tárgyú oktatás több szinten történő integrálása a társadalom mindennapi életében elengedhetetlen követelményként fogalmazódik meg. Az oktatás a fogyasztói magatartás alakításának elengedhetetlen eszköze.

Az oktatásnak több kiemelt területe is megemlíthető, amelyek vonatkozásában érdemes egyes szempontokra külön kitekinteni, így a különböző tárgyalási módszerek megismertetésére, a kollektív gazdasági érdekek megfelelő tudatosítására, illetve egyes korcsoportok fogyasztóvédelmi tárgyú oktatásának kiemelkedő jelentőségére.

\section{(a) A piaci tárgyalási módszerek megismertetése a fogyasztókkal és a kollektív gazdasági érdekek megfelelő tudatosítása}

A fogyasztói szerződések megkötésének folyamatában a szerződést kötő, üzleti, gazdasági tevékenységének körében a fogyasztóval szerződő fél több bevett taktikai módszerrel, tapasztalattal rendelkezhet egy adott területen, mint az adott körben esetleg csak ritkán szerződő fogyasztó. Éppen ezért fontos, hogy a legtipikusabb tárgyalási módszerek a fogyasztó által is megismerhetőek legyenek. A fogyasztók kollektív gazdasági érdekeinek érvényre juttatása ugyancsak megkívánja a fogyasztók megfelelő oktatását.

\section{(b) Egyes korcsoportok kiemelt oktatása}

Az Alkotmány 67. § (1) bekezdése rögzíti, hogy a „Magyar Köztársaságban minden gyermeknek joga van a családja, az állam és a társadalom részéről arra a védelemre és gondoskodásra, amely a megfelelő testi, szellemi és erkölcsi fejlődéshez szükséges". Az Alkotmány a továbbiakban a 70/J §-ban kifejezetten kötelezettségként rögzíti a kiskorú gyermekek taníttatását akként, hogy a „Magyar Köztársaságban a szülők, gondviselők kötelesek kiskorú gyermekük taníttatásáról gondoskodni”. Ezen alkotmányos szintü kötelezettség teljesítése során különös jelentöséget kellene fordítani a fiatalok fogyasztóvédelmi oktatására, akár már a képzési rendszer kialakítása során. A jövő generációinak nevelése alapvető feltétele a tudatos fogyasztói társadalom kialakításának. Pozitív előrelépés ennek tárgyában, hogy a civil szféra mind erősebb érdeklődést mutat annak tárgyában, hogy miként lehetne ezeket az oktatásban még hiányos anyagokat a fiatalabb nemzedék részére közérthető módon eljuttatni, illetve az állam, valamint az Európai Unió is mind erőteljesebb szándékát fejezi ki ezen társadalmi szegmensnek a védelme tárgyában.

Ugyancsak kiemelt társadalmi csoportot jelentenek az idősebbek, akik gyakran esnek áldozatul az új piaci struktúrákban számukra kevésbé követhető piaci magatartásoknak (például a távollevők között kötött szerződések egyes formái vonatkozásában), amelyek tárgyában, ha valamilyen fogyasztói sérelem éri őket, gyakran egyáltalán nincsenek tisztában igényérvényesítési lehetőségeikről.

\section{C) A tájékoztatáshoz való jog}

Az Alkotmány a fogyasztók tájékoztatására vonatkozó kifejezett rendelkezéseket nem deklarál, de egyes külön jogszabályok szabályozási tárgya lett, így például elismerést nyert a megfelelö tájékoztatás kötelezettsége a Polgári Törvénykönyvben is.

A fogyasztó egyfajta elégedettségre vágyik a különböző javak megszerzése által, ám nem ismeri az ehhez szükséges feltételeket a maguk komplex voltában. Ezért van szükség a különböző tájékoztatókra, reklámokra. A kapott információk csökkenthetik a vásárlással szükségképpen együtt járó kockázati tényezőket, viszont adott esetben éppenséggel torz képet 
is adhatnak, hiszen a megfontolt döntéshez nagyobb mennyiségü és pontosabb adat lehet szükséges.[13].

Fontos, hogy a fogyasztó kellőképpen partnerré is válhasson a piaci folyamatokban, ne csupán vásárlói minőségre degradált, alárendelt szerepe legyen. Egyre jelentősebb körben érzékelhető a fogyasztói tudatosság, amely elsősorban az információ hiányos helyzetek megfelelő tájékozódás általi megszüntetésével áll be. Ugyanakkor van több terület is, ahol a fogyasztók tájékozódási szándékát, illetve tájékoztatását erösíteni kellene, így az áru környezetbarát tulajdonságai (összekapcsolható az egészséges környezethez való harmadik generációs jog gyakorlati érvényesülésének biztosításával), az áru társadalmi hasznosságának egyéni értékelése, mint egyfajta ár-érték analízissel (mindenki el tudja dönteni, hogy valójában megéri-e neki az adott árut megvásárolnia, vagy a szolgáltatást igénybe vennie), illetve az áru, illetve szolgáltatás értékesítőjével kapcsolatos korábbi fogyasztói panaszok és elintézésük módjának megismerése (értve ez alatt nem csak a „fekete listák”-at, hanem akár a pozitív hozzáállás megismertethetőségét is) tekintetében[14].

A fogyasztók tájékoztatását biztosító alapvető rendelkezéseket rögzítenek az Fgytv. 8-16. §-ig terjedő rendelkezései. Ezen rendelkezések értelmében a tájékoztatásnak a törvényi rendelkezések értelmében többrétünek kell lennie. Egyrészt alkalmasnak kell lennie arra, hogy a fogyasztó rendelkezhessen az áru- és szolgáltatásválasztás megkönnyítéséhez, továbbá az áru és a szolgáltatás használatához, az áru fenntartásához szükséges megfelelő ismeretekkel az áru és a szolgáltatás alapvető tulajdonságairól, jellegzetességeiről, az áru és a szolgáltatás minőségéről, áráról, díjáról, valamint az áru használatára vonatkozó utasításokról és használatával járó veszélyekről, másrészt pedig képes legyen jogai megfelelő érvényesítésére az ehhez szükséges alapvető ismeretek megszerzésével. Külön szabályok vonatkoznak a címkézésre is. Kiemelkedő jelentősége van ennek, hiszen a fogyasztó gyakran csak az áru megvásárlásának időpontjában, az árun lévő címkéről nyer információkat az áru lényeges tulajdonságairól, nem pedig megelőző tájékozódásai alapján. Az áru pedig csak akkor hozható fogyasztói forgalomba, ha a csomagolásán vagy másutt, de az árutól elválaszthatatlanul elhelyezett címkén jól olvashatóan, közérthetően és egyértelműen tartalmazza a fogyasztók tájékoztatásához és a hatósági ellenőrzéshez szükséges adatokat. Ha az áru jellege indokolja, a címkének külön megfelelő tájékoztatást kell tartalmaznia az áru környezet-, illetve természetkímélő jellegéről, valamint a rendeltetésszerü használatával együtt járó, az áru előrelátható használati ideje alatt fennálló, valamint hulladékká válásakor jelentkező veszélyességi tényezőről úgy, hogy a fogyasztó a veszélyt képes legyen felmérni és megtenni az elhárításához szükséges intézkedéseket. Ezen követelmény érvényesítése komplex szemléletet tükröz, hiszen egyrészt teljesíteni törekszik az egészséghez való jog alkotmányos követelményét, másrészt pedig a környezet védelmét szolgáló rendelkezések által közvetve szolgálja harmadig generációs jogok érvényre jutásának elősegítését is. Amennyiben azt jogszabály elöírja a fogyasztó számára értékesített árut csak használati és kezelési útmutatóval lehet forgalomba hozni. Fontos szabály, hogy a használati és kezelési útmutatóban a fogyasztókat magyar nyelven, közérthetően és egyértelmüen tájékoztatni kell az áru rendeltetésszerü használatának, felhasználásának, eltarthatóságának és kezelésének módjáról, kiváltképpen az áru rendeltetésszerü használatára vonatkozó utasításokról és feltételekről, valamint a minőségének megtartásához szükséges különleges tárolási, kezelési feltételekről, amennyiben azok az áru minőségmegőrzési időtartamát, illetve felhasználhatóságát nagymértékben befolyásolják. Import áruk esetében további követelményeket támaszt a törvény azáltal, hogy elöírja, hogy az árukhoz csatolt idegen nyelvü útmutatóval azonos tartalmú, magyar nyelvü használati és kezelési útmutatót kell a fogyasztó számára biztosítani. Fontos követelményeket támaszt továbbá az Fgytv. az ár feltüntetése tekintetében. Ennek megfelelően az áru fogyasztói forgalomba hozatalakor a forgalmazó köteles a fogyasztót írásban tájékoztatni az eladási árról és az egységárról, illetve 
a szolgáltatás díjáról. A fogyasztók piaci alkupozícióját is erősítő tájékoztatási kötelezettségi elemnek tekinthető az árfeltüntetés tekintetében az a megszorítás, amelynek értelmében az eladási árat, az egységárat és a szolgáltatás díját a Magyar Köztársaság területén törvényes fizetőeszköz szerint meghatározva, egyértelmüen, könnyen azonosíthatóan és tisztán olvashatóan kell feltüntetni. Problémát jelenthet a fogyasztó számára, ha az üzletben több eladási ár vagy szolgáltatási díj kerül egyidejüleg feltüntetésre Ekkor az áru eladási árán, vagy a szolgáltatás díján a feltüntetett legalacsonyabb eladási árat vagy szolgáltatási díjat kell érteni. Amennyiben a gyártó az árut nem látja el a szükséges tájékoztatással és csomagolással, a forgalmazó köteles azt pótolni.

Látható, hogy bár az Alkotmány maga nem deklarálja a fogyasztók tájékoztatáshoz való jogát, de más jogszabályi rendelkezések kellő keretet biztosítanak ahhoz, hogy ez a fogyasztói, ha az alkotmányjog stricta értelmezésében nem is alapjog, mégis mindenképpen élő jog, megfelelően érvényesülhessen.

\section{D) A fogyasztói igények érvényesítésének rendjéről és elveiről, valamint az alapjogok védelméről (jogi védelem és jogorvoslat, mint fogyasztói alapjog)}

\section{(a) A jogérvényesítés alkotmányos alapjai, valamint a békéltető testületi és a polgári peres eljárás, mint a fogyasztói jogviták rendezésének fórumai}

A tisztességes eljáráshoz való jog legfontosabb területe az igazságszolgáltatás. A tisztességes eljárás követelménye az Alkotmány 57.§-ában foglalt valamennyi garanciális szabályt átfogja, mintegy kiegészülve a bírósági szervezeti törvény (1997. évi LXVI. törvény) 9. §-ában foglalt rendelkezéseivel, amely szerint „Mindenkinek joga van ahhoz, hogy bírói útra tartozó ügyét független és pártatlan bíróság tisztességes eljárás során és ésszerű határidőn belül elbírálja”.

Ugyanakkor nyilvánvaló, hogy a tisztességes eljáráshoz való jog követelménye nem korlátozható kizárólagosan a bírói jogszolgáltatásra, hanem ki kell terjednie valamennyi olyan területre, ahol az állampolgár az állami szervekkel mint hatósággal találkozik[15]. Ezt a szellemiséget tükrözi, hogy számos állami szervnek biztosítanak a különböző jogszabályi rendelkezések egyes fogyasztóvédelmi hatásköröket.

Az Alkotmány 57. § (1) bekezdése rögzíti, hogy a „Magyar Köztársaságban a bíróság elött mindenki egyenlö, és mindenkinek joga van ahhoz, hogy az ellene emelt bármely vádat, vagy valamely perben a jogait és kötelességeit a törvény által felállított független és pártatlan bíróság igazságos és nyilvános tárgyaláson bírálja el”. Az igazságszolgáltatáshoz való jog a fogyasztói jogok érvényesítésének tekintetében magában foglalja a megfelelő igényérvényesítést szolgáló eljárásjogi szabályok megteremtését éppúgy, mint a hatékony igazságszolgáltatás követelményét[16].

A fogyasztói jogviták rendezése végett nem csak a bíróságokhoz lehet fordulni, a hatályos magyar jogi szabályozás egy alternatív utat is biztosít, a békéltető testületi eljárást. A békéltető testület az Fgytv. értelmében a területi gazdasági kamarák mellett müködő független testület. A békéltető testület hatáskörébe egyébként az áruk és szolgáltatások minőségével, biztonságosságával és a termékfelelősségi szabályok alkalmazásával, valamint a szerződések megkötésével és teljesítésével kapcsolatos fogyasztói jogviták bírósági eljáráson kívüli rendezése tartozik. Az eljárásra az a békéltető testület illetékes, amelynek területén a fogyasztó lakóhelye vagy tartózkodási helye található.

A békéltető testület eljárása ingyenes, szemben a bíróság eljárásával, így a fogyasztó számára első ízben mindenképpen érdemes a békéltető testülethez fordulni a fogyasztói jogvita rendezésének megkísérlése végett. A békéltető testületi eljárás alapvetően a felek meghallgatására és a közöttük létrejövő megegyezésre épül. Amennyiben azonban a békéltető 
testületi eljárás eredménytelen, akkor továbbra is lehetőség van a jogvita rendezése végett bírósághoz fordulni.

Az Fgytv. indokolása rögzíti, hogy Békéltető Testületek létrehozása azért volt indokolt többek között, mert az Európai Unióhoz tartozó országokban jól megfigyelhető az a tendencia, hogy a bírósági rendszer mellett alternatív vitarendező fórumok jöjjenek létre még ott is, ahol a bírósági rendszer hatékonyan müködik és a Fehér Könyv mellékletének 23. fejezetében elöírt hatékony igényérvényesítési eljárások kidolgozása is szükségessé teszi olyan fórum létrehozását, amely a nemzetközi tendenciáknak megfelelően (olcsón, gyorsan, paritásos alapon) elősegíti a fogyasztói jogérvényesítést, előtérbe helyezve a békéltetést, de bizonyos esetekben döntési hatáskörrel is rendelkezve. Ebböl is következik az, hogy a békéltető testületi eljárás a bírósági eljárás kiváltását, megelőzését szolgálja. Ez pedig okot adhat arra, hogy a békéltető testületi eljárás, mind elveiben, mind pedig eljárási rendjében leginkább magához a bírósági eljáráshoz közelítsen. Az Európai Unió Bizottsága 1998-ban ajánlást fogadott el a fogyasztói jogviták bírósági eljáráson kívüli rendezéséért felelős területekre alkalmazandó alapelvekről. A dokumentum alapelvi követelményként rögzíti a pártatlanság és függetlenség, az átláthatóság, egyenlő elbánás, a hatékonyság, a jogszerüség, a kontradiktórius eljáráshoz való jog, az alávetés és a képviselet elvét. Az Fgytv. hatályos rendelkezései tükrében egyértelmüen megállapítható, hogy a békéltető testületi eljárás megfelel mind a klasszikus eljárásjogi kritériumoknak, mind az Európai Unió által támasztott alapelvi követelményeknek[17].

(b) Az állampolgári jogok országgyülési biztosa

Az ombudsman intézménye Svédországban igen régi jogtörténeti gyökerekkel bír. A svéd mintát követve a 20. század elejétől kezdve több európai ország is beemelte eme jogintézményt jogrendszerébe (például Finnország, Norvégia, Dánia, Nagy-Britannia, Franciaország és Lengyelország). 1985-ben az Európa Tanács Miniszteri Bizottsága 13. számú ajánlásában kiemelten felhívta a tagállamok figyelmét a jogintézmény jelentőségére és lehetőségeire[18]. A Maastrichti Szerződés pedig továbblépve létrehozta az európai ombudsman intézményét. Az EK Szerződés 21. cikke rögzíti, hogy minden uniós polgárnak joga van a 195. cikkben intézményesített ombudsmanhoz fordulni[19]. Ez a jog alapvető része az uniós polgárok státusának.

A rendszerváltás során új intézményként jelent meg az állampolgári jogok országgyülési biztosának intézménye Magyarországon is, az állampolgárokat megillető alkotmányos alapjogok biztosítására. Az állampolgári jogok országgyülési biztosának feladata egyrészt az alkotmányos jogokkal kapcsolatban tudomására jutott visszásságok kivizsgálása, másrészt pedig megfelelő intézkedések kezdeményezése a tapasztalt rendellenességek orvoslása végett. Az ombudsman jogállását szabályozó részletes törvényi rendelkezéseket az 1993. évi LIX. törvény tartalmazza, amely lehetővé teszi, hogy az egyes alkotmányos jogok védelme érdekében külön biztost válasszanak, amelynek értelmében egyes elképzelések szerint érdemes volna esetleg külön fogyasztóvédelmi szakombudsmant is megválasztani, más európai országok bevett gyakorlatának megfelelően[20].

Fogyasztóvédelem új perspektívából: az Európai Unió Alkotmányos Szerződése szintjén

Az egységesebb uniós szabályozási struktúrák kiépítésére azért van szükség, mert tagállami szinten nem érvényesíthető az egységesen hatékonyan az Európai Unió Alapjogi Chartájának 38. cikke által rögzített követelmény, a fogyasztóvédelem magas szintje. A fogyasztóknak egységes igénye a közös piac teljes egészében, hogy bármely tagállamban hozzájuthassanak a legbiztonságosabb árukhoz és szolgáltatásokhoz, valamint a fogyasztók tájékoztatása és igényérvényest lehetővé tevő jogi szabályozás olyan módon valósuljon meg, hogy az európai belső piacba vetett fogyasztói bizalom növekedhessen, ezáltal egyrészt serkentve azt a potenciális vásárlói erőt is, amely tulajdonképpen végső soron a gazdaságpolitika fenntartható 
fejlődés képének szolgálatába állítható, másrészt lehetővé téve azt, hogy az átlagos fogyasztó elérhesse az érdekei hatékony védelmének érzését.

Az európai unió szabályozásának alapvető célja, hogy az egyes árukra, szolgáltatásokra vonatkozó termékbiztonsági elöírások garantálják a fogyasztók személyi biztonságát, egészségének védelmét, a tisztességtelen piaci magatartások és reklámtevékenység visszaszorításával biztosítsa a fogyasztók gazdasági érdekeinek védelmét, megvalósítsa a fogyasztók megfelelő tájékoztatásához szükséges jogszabályi hátteret, a hibás teljesítéssel kapcsolatos, a fogyasztók oldalán keletkező károk rendezésével kapcsolatos hatékony igényérvényesítési rendszerének kiépítse, valamint alapot szolgáljon arra, hogy a tagállamok társadalmi szervezetei minél hatékonyabban bevonhatóak legyenek a jogalkotás folyamatába és a fogyasztók megfelelő oktatásába, tájékoztatásába[21]. A szabályozás ezen területeinek megfelelő megvalósítása nélkülözhetetlen a fogyasztói alapjogok európai uniós szintü érvényesüléséhez.

A közösségi intézmények által gyakorolható közhatalom korlátjaként az alapjogok deklarálásának igénye egyébként már igen korán felmerült az Európai Bíróság ítélkezési gyakorlatában[22]. Az Internationale Handelsgesellschaft ügy kapcsán a Bíróság pedig már a közösségi jogban eleve benne lévőnek látja az alapjogokat, ítéletében olyképpen fogalmazva, hogy a „Bíróság által védett jog általános elveinek szerves része az alapjogok tiszteletben tartása". Annak megítélésében, hogy melyek azok az alapjogok, amelyeknek védelmére a Bíróság joggyakorlata során maga is törekszik, a tagállamok közös alkotmányos hagyományai, valamint az általuk megkötött nemzetközi szerződések szolgálhatnak iránymutatásként.[23]

Külön figyelmet érdemel az Európai Unió Alkotmányos Szerződése, amely annak ellenére, hogy elfogadására még nem került sor kiemelkedő jelentőséggel bír. Az Alkotmány 2006. november 1-jére tervezett életbe lépéséhez minden tagállamnak ratifikálnia kellett volna azt, a Magyar Országgyülés 2004. december 20-án meg is tette azt, azonban Franciaország és Hollandia népszavazáson elutasított. Ennek következtében európai uniós elsődleges jogforrás formájában soha nem léphet majd hatályba, azonban megjegyzendő, hogy egyes rendelkezései azonban a későbbiek során az alapszerződések reformja által azok részeivé válhatnak és bár a részletszabályok a tagállamok között még mindig vita tárgyát képezik, de az alapvető fejlődési irányok meghatározottak, minek következtében külön figyelmet érdemel az alkotmányozás ezen új, immáron a több évszázados nemzetállami hagyományokkal szakítva, a tagállamok határian ténylegesen átívelő folyamata.

Kiváltképpen azért is fontos ez, mert a fogyasztóvédelem, illetve annak alkotmányos alapjait érintő változásokat is előirányoz. A fogyasztóvédelemről elsőként az Unió hatásköreire vonatkozó résznél tesz említés az Alkotmányos Szerződés. A 9. cikk (1) bekezdése értelmében a kiindulópont az, hogy az Unió hatáskörei átadott hatáskörök[24]. A hatáskörök alapvetően három csoportba sorolhatóak. Az első csoportot adja a kizárólagos hatáskörök csoportja, amelyek területén az Unió kizárólagosan fogadhat el, alkothat kötelező erővel bíró jogi aktusokat. A hatáskörök második csoportját a megosztott hatáskörök adnák, amelyek vonatkozásában mind az Unió, mind pedig a tagállamok jogalkotási kompetenciával bírnának, azzal a megszorítással, hogy a tagállamok csak akkor és annyiban élhetnek jogalkotási jogukkal, amennyiben az Európai Unió nem élt ezen lehetőségével. A hatáskörök harmadik csoportja tekintetében az Unió alapvetően koordinatív szerepet vállalna fel, összehangoló, kiegészítő intézkedések meghozatala által. A fogyasztóvédelmi hatáskörök megosztott hatáskörként kerülnének rögzítésre az Alkotmányos Szerződés értelmében. A tagállamok tehát továbbra is alkothatnának különböző fogyasztóvédelmi szabályokat, ugyanakkor ennek egy magasabb szinten érvényesülö keretét adná az Unió szabályozási kompetenciája. Az Alkotmányos Szerződés vonatkozásában azonban külön kiemelendő, hogy a 
fogyasztóvédelmi politika amellett, hogy önálló szabályozás tárgya lenne a továbbiakban is, kiterjedtebb követelményrendszer szintjére is kerülne azáltal, hogy a többi közösségi politika érvényre juttatásának folyamatában is tekintettel kellene lenni a fogyasztóvédelmi követelmények megtartásának szükségességére, ezáltal uniós szinten elismerve a fogyasztói alapjogok érvényesítésének a követelményét.

Függetlenül attól, hogy az integráció elmélyülése során milyen folyamatok dominálnak a jövőben, az alapok kormányközi tárgyalásának kezdete mindenképpen jelzi, hogy egy jelentős volumenü változás elött állunk. Ez a folyamat kedvezően hathat a fogyasztóvédelem fejlődésére is, átláthatóbb uniós szintü kereteket teremtve a fogyasztóvédelem szabályozása számára. Megjegyzendő azonban az is, hogy a megosztott hatáskörök rendszerében a fogyasztóvédelmi szabályok összhangja hozása az uniós szinten egységesülö normarendszerrel újabb kihívások elé állíthatja majd a tagállami jogalkotókat is.

\section{A fogyasztóvédelem fejlődésének jövőben várható tendenciái}

A fogyasztói érdekek védelmét biztosító alkotmányos rendelkezések minél hatékonyabb érvényesítése érdekében folyamatos jogszabályi változásokra van szükség. Ezen változások egyes irányvonalait a belső jogfejlődés által támasztott kihívások indukálják, míg másokat az Európai Unió által elsősorban irányelvi szinten támasztott követelmények adják.

A belső jogfejlődés már-már típus példájának is tekinthető az új Polgári Törvénykönyv tervezete, amely a fogyasztókat érintő szabályozás tárgyában számos jelentős volumenü változtatást irányoz elő. A termékszavatosság jogintézményével bővülne a polgári jognak a fogyasztói igényérvényesítést biztosító rendszere, míg a kötelező jótállás jelenleg hatályos szabályai megszünnének, párhuzamban a kötelező alkalmassági idő jelentéstartalmának újraírásával. A polgári jog szabályainak változása, a magánjogi jogfejlődés ugyanakkor nem csupán az egyetlen és kizárólagos aspektusa a fogyasztóvédelmet érintő jogfejlődésnek.

Ez kiegészül a közjogi szabályok folyamatos változásával is, elsősorban a fogyasztóvédelmi hatóságok szervezetére és müködésére vonatkozó szabályok változásával. A jogfejlődés a fogyasztói jogok egyre szélesebb körben történő biztosítása, illetve a megfelelő jogi garanciák megteremtése szükségességének elismerése irányába mutat. Ennek tárgyában nyilvánvalóan egyrészt szükségez az, hogy az Európai Unió közösségi szintű jogalkotása megfelelő kereteket biztosítson az egyes tagállamok közötti szabályozásbeli különbségek miatt a fogyasztókra nézve kedvezőtlen állapotok megszüntetéséhez, másrészt az, hogy a hazai szabályozás a megfelelő implementálási határidők betartása és a megkívánt szabályozási struktúrák beépítésén túl a rugalmas piaci viszonyokhoz igazodva kellő hajlandóságot mutasson a fogyasztói igények rendezésének új és hatékonyabb módozatainak megteremtése iránt. Egyes elképzelések szerint nyugat-európai mintáknak megfelelően érdemes volna újabb perjogi intézményeket bevezetni a meglévőek mellett, a fogyasztó számára olcsóbb és könnyebben elérhető kvázi bagatell bírósági rendszer formájában[25].

A fejlődés nem állhat meg, a gazdasági élet viszonyai folyamatosan változnak, mind újabb és újabb kihívásokat támasztva a fogyasztóvédelemmel szemben. Ahhoz, hogy az átlagos fogyasztó kellőképpen biztonságban érezhesse magát ezen viszonyok között, függetlenül kedvezőtlen piaci alkupozíciójától, szükséges, hogy legyenek olyan alapvető jogai, amelyek minden körülmények között alapszintü biztonságot teremtsenek számára. A fogyasztói jogok széleskörü elismerése és megfelelő értelmezése emiatt nyilvánvalóan elkerülhetetlen.

A szabályozásnak kellő egyensúlyt kell biztosítania a fogyasztói érdekek hatékony védelme és a fenntartható gazdasági fejlődés között. Amennyiben ehhez az ideális egyensúlyi állapothoz sikerül közelebb kerülni, a fogyasztói társadalom nagyobb elégedettséggel vehet részt a piaci 
viszonyokban, másrészt az üzleti szférának sem lesz érdeke az, hogy mintegy a fogyasztókkal szemben, azok törvényes jogainak csorbítása által biztosítsa saját fellendülését.

Nyilvánvalóan ez abszolút utópisztikus állapot, de a fogyasztói jogok megfelelő biztosítása, a tudatos fogyasztói társadalom formálása elősegítheti azt, hogy mind közelebb kerülhessünk ahhoz, hogy a fogyasztó és a vele szerződő fél ne csupán kényszerü piaci partnerei legyenek egymásnak, hanem kapcsolatuk mintegy ténylegesen is a kölcsönös együttmüködésen alapulhasson.

\section{Felhasznált irodalom, jogszabályok és AB határozatok}

\section{Irodalomjegyzék}

1. Andorka Rudolf : Keynes általános elmélete (Valóság, 1966. május) 79-85. o. és (http://tek.bke.hu/keynes120/magyar/bevezeto.html)Dezső Márta-Fürész Klára- Kukorelli István - Papp Imre - Sári János - Somody Bernadette - Szegvári Péter - Takács Imre : Alkotmánytan I. (OSIRIS KIADÓ, Budapest 2007)

2. Kátai Anikó: Fogyasztóvédelem az Európai Unióban (Magyar Köztársaság Külügyminisztériuma, http://www.kulugyminiszterium.hu/NR/rdonlyres/96B3BC078E2F-49C3-8B5B-1625F42C4D23/0/fogyaszt\%C3\%B3v\%C3\%A9delem.pdf)

3. Mező István: Fogyasztóvédelem az Európai Alkotmányban (Fogyasztóvédelmi Szemle, 2005/2)

4. Fazekas Judit: A fogyasztóvédelem alkotmányos alapjai (Sectio juridica et politica, jubileumi kötet a Miskolci Egyetem fennállásának 260. évfordulója alkalmából, Miskolc, 1995)

5. Kozák Ákos: A fogyasztás változó világa (Fogyasztóvédelmi Szemle 2005/különszám)

6. Nagy Ferenc: A magyar büntetőjog általános része (Korona kiadó, Budapest, 2003)

7. Miskolczi Bodnár Péter - Szuchy Róbert: A fogyasztóvédelmi jog kialakulása, gazdasági és jogi alapjai (www.uni-miskolc.hu/ wwwkerjo/fogyvedkialak.ppt)

8. Sári János: Alapjogok (Osiris Kiadó, Budapest, 2003)

9. Sós Gabriella: Alapelvek a békéltető testületek eljárásában (Collega 2002/1)

10. Szöllősy András: a fogyasztói döntések szabadságának védelme és a versenyjog - a fogyasztóvédelmi politika és a versenypolitika kapcsolata ( http://www.gvh.hu/domain2/files/modules/module25/pdf/print_4450_h.pdf)

11. Várnay Ernő-Papp Mónika: Az Európai Unió joga (KJK-KERSZÖV, Budapest, 2005)

\section{Jogszabályok és AB határozatok}

1. 1949. évi XX. törvény a Magyar Köztársaság Alkotmánya

2. 1959. évi IV. törvény a Polgári Törvénykönyvröl

3. 1997. évi CLV. törvény a fogyasztóvédelemről

4. 1997. évi LXVI. törvény a bíróságok szervezetéröl és igazgatásáról

5. 33/1993 (V. 28) AB határozat

6. 21/1994 (IV. 16.) AB határozat

7. 32/1991 (VI.1.) AB határozat 
[1] Egyetemi tanársegéd, Debreceni Egyetem Állam- és Jogtudományi Kar, Polgári Jogi Tanszék

[2] Miskolczi Bodnár Péter - Szuchy Róbert: A fogyasztóvédelmi jog kialakulása, gazdasági és jogi alapjai (www.uni-miskolc.hu/ wwwkerjo/fogyvedkialak.ppt)

[3] Andorka Rudolf : Keynes általános elmélete (Valóság, 1966. május) 79-85. o. és (http://tek.bke.hu/keynes120/magyar/bevezeto.html) alapján

[4] Nagy Ferenc: A magyar büntetőjog általános része (Korona kiadó, Budapest, 2003) 52-53. o.

[5] Sári János: Alapjogok (Osiris Kiadó, Budapest, 2003) 17-22. o., 37-38. o.

[6] i.m Sári János 153. o.

[7] Fazekas Judit: A fogyasztóvédelem alkotmányos alapjai (Sectio juridica et politica, jubileumi kötet a Miskolci Egyetem fennállásának 260. évfordulója alkalmából, Miskolc, 1995) 153. o.

[8] Mező István: Fogyasztóvédelem az Európai Alkotmányban (Fogyasztóvédelmi Szemle, 2005/2) 21. o.

[9] Várnay Ernő-Papp Mónika: Az Európai Unió joga (KJK-KERSZÖV, Budapest, 2005) 65. o.

[10] i.m Várnay Ernő-Papp Mónika 153-154. o.

[11] i.m Sári János 195-199. o.

[12] i.m Fazekas Judit 154-158. o.

[13] Szöllősy András: a fogyasztói döntések szabadságának védelme és a versenyjog - a fogyasztóvédelmi politika és a versenypolitika kapcsolata 5-12. o. alapul vételével ( http://www.gvh.hu/domain2/files/modules/module25/pdf/print_4450_h.pdf)

[14] Kozák Ákos: A fogyasztás változó világa (Fogyasztóvédelmi Szemle 2005/különszám) 12.o.

[15] i.m Sári János 93. o.

[16] i.m Fazekas Judit 158. o.

[17] Sós Gabriella: Alapelvek a békéltető testületek eljárásában (Collega 2002/1) 75. o. és 78. o.

[18] Dezső Márta-Fürész Klára- Kukorelli István - Papp Imre - Sári János - Somody Bernadette - Szegvári Péter - Takács Imre : Alkotmánytan I. (OSIRIS KIADÓ, Budapest 2007) 475. o.

[19] i.m Várnay Ernő - Papp Mónika 63. o.

[20] i.m Fazekas Judit 159. o.

[21] Kátai Anikó: Fogyasztóvédelem az Európai Unióban (Magyar Köztársaság Külügyminisztériuma, http://www.kulugyminiszterium.hu/NR/rdonlyres/96B3BC07-8E2F49C3-8B5B-1625F42C4D23/0/fogyaszt\%C3\%B3v\%C3\%A9delem.pdf)

[22] Mező István: Fogyasztóvédelem az Európai Alkotmányban (Fogyasztóvédelmi Szemle 2005/2) 20. o.

[23] i. m Várnay Ernő-Papp Mónika 232-223. o.

[24] i. m Várnay Ernő -Papp Mónika 81. o.

[25] i.m Fazekas Judit 158.o 